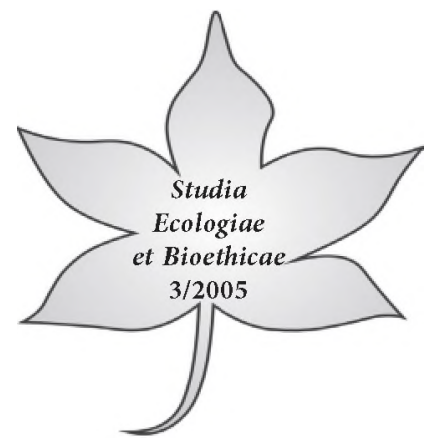

\title{
Internet as source of information about environmental protection
}

The rapid development of the Internet, which we are seeing during the last several years creates new possibilities for acquiring information about the problematic issue of environmental protection. Thus far known forms constituting access to information such as books, professional magazines, information bulletins are beginning to be less appreciated by those interested in the subject. Many factors compound this situation.

The research I have conducted among students of UKSW (University of Cardinal Stefan Wyszyński in Warsaw) indicates, that the main obstacle in accessing information passed on in a traditional manner is the cost of its acquisition as well as technical difficulties in reaching the source of the said information. Students placed the following as other factors: lack of time in seeking information, lack of knowledge about availability of specific data on the information market, the need to immediately find diversified information. Social researchers, Marshall McLuhan and Walter Ong working with analysis of traditional communication in print claimed, that acquiring the same data through the Internet is related to the new need for finding information, which was not available in a traditional format. This new need is the acquisition of information based on fragmenting knowledge. Reality is a collection of information elements placed next to one another connected with links to other Internet pages. In effect, the picture which we obtain when seeking information is a composite composed according to hierarchy giving a general impression about a certain problem. This hierarchy is a collection of information and links connected with it. This precise diagram remains as the single and final source of information. With this format of information access based on such incidentally found diagrams and interrelations, those looking for information create images about phenomena, processes or concepts. From this form in turn rears another disquieting process, and that is the lack of any point of reference or information authentication. It is all the more a dangerous process since increasingly more information input into the web network derives from an unknown source and is presented in an anonymous form. A certain form of organizing information (at a search engine level) available on the Internet are, certainly, all types of catalogues. Catalogues, however, have 
been designed on a certain far reaching level of general. In case of the problematic issue of quintessential basics making up the problem of environmental protection, the generally accessible Internet catalogues fail to meet their task. Under these circumstances the only tool remaining are web search engines.

Yet, search engines also have their limitations. For that reason, in order to improve the efficacy of a search for information the so called "meta search engines" should be looked into by those searching for information using several tools simultaneously. Another method, which might bring better results is the application of software acting as search tools but having their own search engines. The said engines, for example, enable a search in such a way so as to remove duplicated search results. An example of the aforesaid are: Copernic Agent, BullsEye and others.

Yet, still another method of looking for scientific information is using subject catalogues. Also known as resource guides, webliographies or cyberguides. These catalogues are on the web in a form of reference directing to sources of a closely defined scientific problematic subject matter. The simplest way of finding a subject catalogue is by entering an appropriate phrase into WWW.teoma.com. - a dedicated website.

Subject catalogues may also be looked for using today's popular search engines such as: Google, AltaVista or others. In this case, the only condition is for the search engines to have a catalogue search function. An example of a specialized subject catalogue is BUBL LINK (bubl.ac.uk/link) devised at the University of Strathclyde. This catalogue contains a collection of approximately 12000 web pages on all practiced scientific disciplines.

Subject catalogues are characterized by a high level of selectivity, however, their actual efficacy in searching for information on environmental protection still leaves much to be desired.

All of the thus far described techniques of searching for scientific information pertain to that data, which in some type of form have been generated by the search engines. It should be kept in mind, however, that a disproportional amount of information is only available on the net. The fact of its potential existence relates to the fact, that they are invisible (Invisible Web or Deep Net). Experts in the field of scientific information on the net believe, that invisible resources are five hundred times greater from those which may be seen. First of all, these sources contain an enormous amount of data bases, statistics and documents. The fact, that these sources are "invisible" does not by any means tie in with a fact that they are confidential. Their invisibility is part due to the fact of not being registered in the search engines index and partly due to technical reasons. In this case I am referring to technical errors made during their construction. The most frequent mistake is creating multimedia Flash main pages, which replace text index pages. Portals thus constructed are frequently improperly indexed or not indexed at all by the search engines. Until 2001, search engines didn't even index PDF and DOC formats. 
In searching for valuable scientific data, which most often are in databases an additional difficulty is in accessing them after authorization. The authorization process itself, of course, does not constitute a problem. The problem, however, is in indexing those databases by the search engines. In an event when the said databases area accessible only after authorization, it is automatically related to the fact, that they are not properly indexed by the search engines.

Registering such web portals on "invisible pages" lists is one solution to this mad cycle. Examples of such list are, for example: WWW.invisible-web.netaip. completeplanet.com and WWW.freepint.com

Also, materials access to which is possible only at a fee are also invisible in search engines. Most frequently, however, this pertains to information collected in a form of articles or databases of various types of magazines online. A somewhat different set of rules dictates methods of reaching these texts. Another group of inaccessible information is data place on dedicated server for a specified group of users. For example, magazine article texts published by Oxford University Press are available at a fee but also exclusively for organizations. Limitations also pertain to their print documents where there applies a separate procedure. In our country, access to, for example the Encyclopedia Britannica is guaranteed only to its members by the British Library of the British Council Poland.

Users who find Internet encyclopedia portals must also realize, that the text contained in the online services most often does not match the printed information. There is also a difference in access to data alone on online services. A significant amount of information pertaining to the professional problematic issue of environmental protection may be found looking through library databases of books and magazines. In our country such a database is made available by the National Library and the Library of the University of Wrocław WWW.bu.uni. wroc.pl. When it comes to world library resources then the largest database may be found on the American Library of Congress webpage: WWW.loc.gov. In case of this database looking for information cannot be carried out by using a phrase or a keyword. Resources may be searched through by entering the users last name, title or ISSN or ISBN numbers. For that reason, in order to effectively be above to use the aforesaid databases one should earlier obtain proper library information through Web of Science of the Thomas company WWW.scientific.thomas.com

When searching for information on environmental protection using web search engines more frequently we find ourselves on pages of professional magazines online. This access, however, is partial and incomplete (only abstracts are available) as the text of the materials we are looking for is most often available at a fee.

An interesting form of publication of scientific materials on the Internet are the so called e-preprints. The said materials are "trailer" texts appearing prior to the publication of the proper full texts. Currently, there rare several scientific service websites on e-preprints. E-preprint Network WWW.eprints.osti.gov is 
one of the better known services primarily focusing on scientific issues. American Cornell University's archive WWW.arxiv.org also deserves to be looked into. In our country the Internet Word of e-preprints is run by the Computer Information and Mathematics Institute of the Mikołaj Kopernik University in Torun.

Using generally available search engines one can find web pages of electronic professional magazines existing within the Open Access initiative. This is an initiative, thanks to which scientists publish their texts without charging a fee. That is why the said materials are available online. One of the most respectable catalogues on the web containing published material through the Open Access portal initiative database is WWW.doaj.org and the catalogue of the Library of the Houston University under the following address: WWW.info.lib.uhedu.

The most modest database on the Internet pertaining to the issue of environmental protection is books. This is primarily due to the fact, that most of the texts available on the Web comes from before 1920, as all later published material is protected by copyrights. One of the largest and professional databases of the above said publications is Project Gutenberg: WWW.gutenberg.org and the Online Books Page WWW.onlinebooks.library.upenn.edu. In domestic resources there are no similar projects to date, which would contain material on the issue of environmental protection.

This short analysis of Internet resources on the subject of environmental protection issues shows how huge the resources are and what's more they are being added on to on an ongoing basis. Resources enriched and increased by both scientists as well as higher efficacy organization activists, professional digitizers and finally everyday Internet amateurs. As we see, the enormous amount of information with which we are faced is not equivalent with automatic access to the said information. Internauts looking for information must not only have the essential knowledge about Internet resource structure but also have unique abilities in searching techniques looking for information on environmental protection. And here, we come back to the beginning about deliberating on the subject, not only the web search workshop alone but also the ability to properly assess Internet websites, web pages or portals.

Searching for information using a search engine for that purpose and putting in specifically selected keywords or concept phrases is one of the ways by which to access information about issues not only on the subject of environmental protection. This search method, at this time most certainly the most popular among the Internauts carries with it many substantial difficulties. On one hand these are difficulties based on a proper choice of phrases and on the other a proper choice means the actual value of the found pages. I wrote about the difficulty in selecting and using appropriate phrases or keywords at the beginning, now I would like to focus on the techniques of assessing web pages.

Despite the undisputed progress of technology even the best search engines function based on technology, which actually is not capable of assess intrinsically 
the WWW pages searched by you. The data search technology progress is great nevertheless, one still finds a great deal of web pages, the contents of which speaking in most general terms "deliberately" makes an error in tools used by the search engines. Here, I will not carry on about why this is so but rather immediately move on to the most significant problem being how to recognize the so called "reliable" websites. Websites containing data, which we simply can rely on. A proper elemental assessment of the found pages is generally not easy and conclusively defined. This process requires a significant amount of knowledge not only of the subject on which our search is based on, in our case on the subject of environmental protection, but also on the assessment process of the found websites. In the process of proper assessment of found WWW pages on the Internet we should first of all be directed by the following guidelines:

- Assess the source of the WWW page,

- Find out who is actually the owner of the WWW page,

- Check who is the actual owner of the domain on which the WWW page is found,

- Try to assess the WWW page from the angle of its actual objectives, which it is to fulfill on the Internet (education, information, entertainment, commerce, etc.),

- Make an initial assessment of the editorial, grammatical and stylistic level used by the authors of the WWW page being assessed,

- Evaluate the example bibliography material,

- It should always be noted whether the page is being updated,

- Assess the IT technology level, on the basis of which the WWW page, portal or site was constructed,

- Evaluate and assess the level of graphics represented by the WWW page, in this excluding first and foremost pages built on Flash graphics.

The result of my research conducted among students of UKSW confirm a very low effectiveness in finding specialized information on environmental protection. This is primarily due to certain basic errors in the education process itself. Education on specialized subject matter such as environmental protection does not keep up with the changing process of access to information on the Internet. The conducted research showed two weakest links of this process. One ensues from a lack of a comprehensive environmental protection program in the currently functioning education systems, constituting a holistic approach to the issue of pro-ecology education. Most universities and colleges offering a curriculum on this subject matter at best offer subjects relating to education on the environment such as, ecology, environmental protection, geology, hydrology, soil specialization, biology, toxicology etc.

The second problem comes from a very low level of knowledge by the students about the laws governing the World Wide Web. The very fact, that the second problem exists has its direct roots also in system of IT education in colleges and universities in our country. 


\title{
Bibliography
}

COHEN J., The unusually useful Web Book, Pearson Education, 2004.

Danowski D., Swiat według Mozilli, Firefox, Helion 2005.

Guide to LIFE website, European Commission, DG ENV, UE 2005.

Jones A., Duck R., Reed R., Weyers J., Nauki o środowisku, Ćwiczenia praktyczne PWN 2002.

Kitajewski M., Google, ćwiczenia praktyczne, Helion 2005.

SoKó M., Sokó R., Internet, jak surfować bezpiecznie, Helion 2005.

Thurow S., Search engine visibility, Pearson Education, 2004.

VAssos T., Strategic Internet Marketing, Tom Vassos 1999.

\section{Internet jako źródło informacji o ochronie środowiska}

\author{
STRESZCZENIE
}

Gwałtowny rozwój Internetu, jaki obserwujemy w ostatnich latach, stwarza nowe możliwości pozyskiwania informacji o problematyce ochrony środowiska. Dotychczasowe formy dostępu do informacji w postaci książek, czasopism specjalistycznych, biuletynów informacyjnych stają się coraz mniej doceniane przez zainteresowanych. Na ten stan rzeczy składa się wiele czynników.

Z badań, które prowadziłem wśród studentów UKSW wynika, że główną barierą $\mathrm{w}$ dostępie do informacji przekazywanej formą tradycyjną jest koszt w postaci jej pozyskania oraz trudności techniczne w dotarciu do źródła informacji. Na kolejnych miejscach wskazanych przez studentów, znalazły się następujące czynniki: brak czasu na poszukiwanie informacji, brak wiedzy o dostępności konkretnych danych na rynku informacji, potrzeba natychmiastowego dotarcia do zróżnicowanej informacji.

Wyniki moich badań prowadzone wśród studentów UKSW, potwierdzają bardzo niską skuteczność w poszukiwaniu specjalistycznej informacji w zakresie ochrony środowiska. Związane to jest przede wszystkim $\mathrm{z}$ pewnymi merytorycznymi błędami w samym procesie edukacji. Programy w zakresie edukacji przedmiotów specjalistycznych w zakresie ochrony środowiska, nie nadążają za zmieniającym się procesem dostępu do informacji w sieci Internetowej. Przeprowadzone badania wykazały dwa najsłabsze ogniwa tego procesu. Jeden wynika $\mathrm{z}$ braku w obecnie funkcjonującym systemie edukacji, kompleksowego programu edukacji środowiskowej, stanowiącego systemowe holistyczne podejście do problematyki edukacji pro-ekologicznej. Na większości uczelni wyższych zajmujących się tą problematyką, przedmioty związane $\mathrm{z}$ edukacją środowiskową w najlepszym przypadku występują w postaci niezależnych przedmiotów, np. ekologii, ochrony środowiska, geologii, hydrologii, gleboznawstwa, biologii, toksykologii itp.

Drugi powód wynika $\mathrm{z}$ bardzo słabej znajomości wśród studentów praw, jakimi rządzi się Ŝwiatowa Sieć Internetowa. Fakt istnienia, tego drugiego powodu ma swoje bezpośrednie korzenie również w samym systemie edukacji informatycznej na wyższych uczelniach w naszym kraju. 